\title{
Non-oil exports and employment in Iran during 1980 to 2009
}

\author{
Sevda Yaprakli ${ }^{1}$, Shahryar Fathi Mollaee ${ }^{2 \star}$ and Ali Besharat ${ }^{3}$ \\ ${ }^{1}$ Faculty of Economics and Administrative Sciences, Atatürk University, Erzurum, Turkey. \\ ${ }^{2}$ Department of Economics, Islamic Azad University, Malekan Branch, Malekan, Iran. \\ ${ }^{3}$ Department of Economics, Islamic Azad University, Maragheh Branch, Maragheh, Iran.
}

Accepted 17 August, 2012

\begin{abstract}
Economic goals, such as efforts to optimize resource allocation, offset of income distribution and economic growth are very important for all nations. According to economic plans in Iran, Gross National Product (GNP) should increase at least $8 \%$. One of the important factors for obtaining this essential goal (economic growth more than $8 \%$ ) is to reduce unemployment rate to $7 \%$ and increase employment rate. Increase in non-oil exports can affect aggregate demand and reduce unemployment. In this paper we have studied the relationship between unemployment and non-oil exports using econometric methods such as ordinary least squares (OLS). Non-oil exports should be considered as one of the strategies for reducing unemployment, by economic agents and policy makers. Statistical data, and time series data is collected from central bank and through internet sites of formal statistical organizations. According to experimental results the logarithmic functions show better estimates, so the logarithmic functions are used to estimate and explain the relationships between variables. Results showing that the research hypothesis that increases non-oil exports, increase employment and reduce unemployment during the study period, would be accepted.
\end{abstract}

Key words: Economic growth, employment, non-oil exports, unemployment rate.

\section{INTRODUCTION}

Unemployment and its effects on economic variables is one of the most important problems that the economies are faced with and full employment is one of the most important goals of governments. The prerequisite for achieving sustainable growth and development is efficient utilization of production resources.

Unemployment crisis in Iran's economy is a life-long term for economic and social problem that threatens the country. With rapid population growth in the last three decades, the needs for job opportunities with the increase of population have grown. On one hand, the study of population growth during the past 30 years vindicates this explanation. High population growth rates in the country, witnessed in 1967 to 1977 increased to $3.91 \%$ per year. Population of those born in this decade

\footnotetext{
*Corresponding author. E-mail: fathimollaee@gmail.com.
}

with a 20 to 25 years delay in the labor market in 1991 and 2001 were used and the supply rate of the labor force were added (Amuzegar, 2004).

On the other hand, the rapid expansion of students attracted to universities after the war, lead to a reduction in the amount of labor force available in the labor market and after graduation there was an increase in labor supply. The rate of women's participation in economic and social affairs and their presence in the labor market was increased. Decreasing in purchase power of households also triggered an increase in labor supply. Consequently, in recent years we have experienced an increase in labor supply rate and it is predicted that it will be increased in subsequent years (Karimi, 2008). Consequently, decision makers should consider such information when they are planning.

Finally regarding to the importance of employment the study is organized to determine the effect of non-oil exports increasing on employment. 


\section{THEORY OF EMPLOYMENT}

According to theoretical foundations of employment; employment is the act of being involved in recruitment and occupation, employment condition, which includes wage earners and those who work for themselves. The acting population $\mathrm{N}_{\mathrm{a}}$ is that part of the workforce $\mathrm{N}_{2}$ who are currently employed in general and are counted and determined by housing census. All active people include those who in the past seven preceding days do similar work. Employment rate is percentage of the working population to total population. So we can write:

$E R=100\left(\mathrm{Na} / \mathrm{N}_{2}\right)$

Full employment is a common situation, in which everyone wants to work with given wages that can be achieved through the opportunity of work. The main concept of full employment in the economy does not mean zero unemployment but a level of unemployment that the economists have called the natural unemployment rate, and it is consistent with full employment status (Froyen, 1998).

Factors like lack of information about job seekers and the absence of knowledge of the existence of the vacancy, the mobility of the different geographical areas, and special characteristics of people with different expertise levels and so on, deters the unemployment rate from falling to zero. So in an economy the number of unemployed in full employment conditions can be greater than zero.

Incomplete employment arise when the laborers receive wages based on full-time employment, but they are not used in the work all the time, vice versa, when workers seeking full-time job are only able to find parttime work, there is incomplete employment (Valadkhani, 2003).

Adam Smith, the founder of classical economics, had believed that the main source of wealth is the human work. Smith in the first line of his book- the wealth of nation; about the nature of wealth - had written about the basic motif, that all things are necessary and useful for the preparation of goods and services.

People, who are employed to produce the products, include direct labor and all the things that can be purchased by it from the outside. Smith had believed that an increase in wages, which piles up more force on staff health and life expectancy of a professional leads to doing more work. Smith believed that the main reason for the expansion of industrial revolution is competitive conditions in the economy and so he has emphasized the lack of government intervention in economic activities. In the classical theory of employment, labor market was a competitive market and full employment has been assumed. The only variable factor of production in the classical model is human force. Capital input -the device is absorbed in the labor factor so it does not cause unemployment. Thus, classical economists believe that the equilibrium is always stable at full employment. The emergence of involuntary unemployment in the economy is as a result of voluntary unemployment accumulation to the neck of the working people who have stretched theirs. The classical view of the limited amount of unemployment in the community there is a natural interpretation is that unemployment.

The incidence of major recession and vast unemployment, poses skeptic and hard questions on the classical theory of employment and to begin preparations for the construction of another school. Old classical view is that unemployment is a macroeconomic issue in the area. The classical terms of involuntary unemployment is a short-term phenomenon, which is the difference between prices and wages and rising real wages, resulting in an involuntary outbreak of unemployment. Wage levels should be reduced in classical thought and involuntary unemployment in the economy would be reduced. Except for those out of work and the time interval between the losses of jobs, the unemployed finds new jobs (Sexton, 2008).

Consecutive economic crisis and expanded unemployment among people who seeking jobs -does not absolutely interpret natural unemployment- many critics of the classical theories proposed. Before the beginning of the twentieth century, the reaction created adverse economic conditions. In the work of socialist's lack of unfair distribution of income was the attention and emphasis. But among these ideas; the ideas of John Maynard Keynes had created a revolution and transformation in particular economic thought. Socialist critics of classical theories, rejected capitalism and called for the creation of new economic and social spheres but Keynse's demanded reforming capitalism emphatically and fluctuating decline be continued with more coherence and strength of this system.

Keynes believed that in the twentieth century, there is no perfect competition conditions and quality and quantity of market foundation has changed. Full employment equilibrium, is spontaneous and always in the labor market and there is no involuntary unemployment, because there is money illusion near the workers and nominal wages are inflexible. According to Keynes, willingness of workers to accept less money is not necessarily the solution for unemployment. However, reduction in money wages ultimately lowers the cost of production at the company and will increase production and employment. But if there is decreased wages in all of the firms, ultimately aggregate demand will reduce and will give birth to serious negative impact on investment and employment.

His comments contrast with the classical labor supply function as direct monetary compensation. Keynes showed that money wages instead of price decreases may reduce the tendency to undermine investment.

According to the theories of Keynes and his followers, 
there is insufficient investment and the liquidity trap can be prevented from full employment equilibrium. Consequently, in government intervention in economic affairs applying financial policies is the only scientific and practical means for moving the economy toward full employment .

\section{Theoretical foundations of non-oil exports}

The term of export is derived from the conceptual meaning of shipping outputs out of the port of a country. The seller of such goods and services is referred to as an exporter who is based in the country of export whereas the overseas based buyer is referred to as an importer (Joshi, 2005).

\section{Non-oil exports of Iran's economy}

In Iran's economy, exports are divided into two types; oil exports and non-oil exports. Non-oil exports are divided into three sections:

1. Export of agricultural goods;

2. Export of manufactured goods.

3. Export of mineral and building facilities (Goharian, 1995).

Iran's non-oil exports have surpassed 13.2 billion dollars during the first four months of the current Iranian year, says Iran's Minister of the Economy. Hosseini, said on Tuesday that the figure reflects a $42.5 \%$ increase in value of Iran's non-oil exports in the first four months of this Iranian calendar year (beginning March 21), compared to the same period last year.

The minister added that the country also imported about 18.4 billion dollars of goods during March 21 and July 22 -down $3.5 \%$ compared to the same period last year. Hosseini noted that the implementation of subsidy reform plan and the increase of the country's production capacity led to the decrease of Iran's imports. Last month, Iran's President Mahmoud Ahmadinejad said that the oil-rich country is prepared to increase its non-oil exports to more than 45 billion dollars in the current Iranian year.

President Ahmadinejad went on to say that Iran's nonoil exports surpassed 30 billion dollars in the past year. Iran's non-oil export items mainly include gas condensates, mineral fuels, chemical products, plastics, fruits, nuts, fertilizers and carpets.

The International Monetary Fund (IMF) said in its latest report that Iran's economy grew by $3.2 \%$ in 2011 , which is by far higher than earlier reports on the country's economic performance. The IMF said Iran was successful in containing inflation in the aftermath of its subsidy reform plan falling from an average of $25.4 \%$ in
2008-09 to an average $12.4 \%$ in $2010-11$.The organization also hailed the Iranian government's economic reforms which include distribution of monthly cash reimbursements, targeted at the poorest Iranians, to replace subsidies.

The measures will move as much as $\$ 60$ billion in subsidies, or $15 \%$ of Iran's gross domestic product, the IMF said, adding that they will "increase the efficiency and competitiveness of the economy, improve income distribution, reduce poverty and help Iran unlock its full growth potential." The subsidy reform plan, which was implemented in October 2010, charts out how the Iranian government will gradually slash national energy subsidies over the course of five years, with low-income families being compensated directly with cash subsidies (Press TV, 2011).

\section{Non-oil exports and increase production capacities}

According to theories and experimental results of research, actual production forms based on demand. Demand may be caused by internal or external factors. The lack of external demand will cause the production based on domestic demand. So despite the possible and potential supply, production capacity will not be fully used. It is natural that the unused capacity can be used to satisfy the foreign demand (Mehdi, 2011).

\section{Non-oil exports and job creation}

Non-oil exports affects all economic variables and all part of economy especially employment. We can find the cases of non-oil exports effect on employment, on production, collection, packing, exporting and marketing. In the field of manufacture and agricultural production it is natural that only domestic demand is the production of unemployment until the equilibrium between supply and demand, can increase employment. On the other hand, if the products are also exported to foreign markets, there is increased demand for production of more goods; consequently, there is possibility of providing more employment.

There are some studies in the case of foreign trade and exports. Gourdon et al. (2006) in a study entitled "Openness, Inequality, and Poverty: Endowments Matter" have tried to examine the relationship between trade liberalization and income distribution and relative factor endowments. The results show that in countries where workers have higher skills, less income inequality is theoretically valid when there are no trade barriers. If free trade is:

1. Control of the business, inventory resources, as well as income inequality explains.

2. Freedom of investment business in countries where 
Table 1. Fuller unit root test results in Table Dickey added (ADF).

\begin{tabular}{lcc}
\hline Variable & $\boldsymbol{t}$-Statistic & Critical amount (\%) \\
\hline EM & 2.19 & $2.96-5$ \\
NOE & 0.2 & $2.96-5$ \\
P & 5.23 & $2.96-5$ \\
GNP & $1.96-$ & $2.96-5$ \\
\hline
\end{tabular}

income inequalities are reduced.

3. The freedom of trade and income inequality in countries with abundant skilled labour force increases (Abu Anvari and Khoshkar, 2006).

\section{DATA AND METHODS}

This study reviews the non-oil exports and employment in Iran. In this study to examine the relationship between employment and non-oil exports from the figures relating to the non-oil exports, GDP, employment and inflation has been used. According to primary results, the logarithmic model gave the best estimate of coefficients, so the logarithmic variables are used. General model of this of Research are as follows:

$\operatorname{LnEM}=f(\operatorname{InNOE}, \operatorname{InGNP}, \operatorname{InP})$

LnEM the logarithm of employment, InNOE logarithm of non-oil exports, InGNP logarithm of GDP and InP is the logarithm of price index. In this model employment is used as the dependent variable and other variables are used as independent variables. Time-series of annual statistical information required has been extracted by the Central Bank of Iran during the study period 1980-2009 (CBI, 2011). Finally OLS method and the Eviews software are used to estimate coefficients of the model (Shirinbakhsh and Khansari, 2005).

\section{Reliability and stationary test of variables}

Stationary variables of the unit root test for generalized Dickey Fuller (ADF) was used. In this test hypotheses are as follows:

$\mathrm{H}_{0}$ : Transience exist

$\mathrm{H}_{1}$ : Transience does not exist

If the hypothesis is rejected, the hypothesis non-stationary series will be stationary series. Accepting or rejecting the hypothesis test is based on the $t$ statistic. If the absolute value of the $t$ statistic is greater than the critical value, the hypothesis can be rejected based on non-stationary (Gujarati, 1992). And the series will be stable. The unit root test in Table 1 is shown. Dickey-Fuller (DF). Fuller unit root test results in Table Dickey's addition (ADF).

According to Table 1, ADF test results on the variables, anyvariables other than $p$ (inflation) are at the stationary level. This is because the absolute value of $t$ statistic is larger than the critical value at $5 \%$ level, showing that some of the variables $I(0)$ and others are not at stationary level, (that is, I(1) or I(2) are ) the convergence test should be performed on variables.

Independent sample in OLS Engel - Granger convergence between variables can be used for diagnosis. Engel - Granger unit root tests on the waste model does, that way if the wastes $(\mathrm{u}), \mathrm{I}(0)$ are. If all the variables are $I(d)$, but variable, $U, I(b)$ is a condition that $b$ is smaller than $d(b<d)$, the series will converge. Parasite test - showed Grinjir I(0) model is a waste.

\section{Tests to estimate the model using OLS}

White independent sample test for heteroscedasticity is used. To test this hypothesis

$\mathrm{H}_{0}$ : No heteroscedasticity

$\mathrm{H}_{1}$ : Presence of heteroscedasticity

Accept or reject this hypothesis based on $\mathrm{F}$ statistics test and also the least likely to be confirmed. If the F statistic is accepted, the model has no heteroscedasticity (. White test statistic $F$ and $(F)$ Prob as the following shows. Prob (F-statistic $)=0.08$, F-Statistic $=$ 2.12

Note that $F$ statistics greater than 2 and less than $5 \%$ is likely, therefore, the hypothesis cannot be ruled out as having no heteroscedasticity.

\section{RESULTS}

Eviews software output estimated by OLS method of adding variables to the model and eliminates heteroscedasticity is presented in the following values:

LNEM $=10984376+3.35 L N G N P+426.63 L N N O E+88343.53 L N P+0.92 M A$

T-statistic value (30.23) (2.82) (2.70)

Table 2 shows the estimated value of coefficients and parameters of the model via OLS method. The other statistics such as t-Statistic and F-statistic are reported. So these statistics can help us, if we want to test the significance of a particular factor. For example if the absolute value of the $\mathrm{t}$ - statistic is greater than critical value of $\mathrm{t}$, the coefficient is significant. Otherwise the coefficient is not significant and the variable cannot have a significant effect on the dependent variable.

Thus, according to Table 2 and the $t$ statistic associated with each of the independent variables, the coefficients are all significant and all of independent variables have a significant effect on the dependent variable.

Also in this table, statistical quantities such as the coefficient of determination and standard deviation of wastes and other items are calculated. The quantity tables Durbin Watson statistic (DW) is used to detect the presence or absence of autocorrelation of the disruption sentences. Due to $(\mathrm{DW}=1.51)$ in the table the disturbing statements of solidarity approximately is solved adding MA (1) to the model.

The R-Square is another important statistic in a table that penetrates the coefficient of the model. The value of this statistic that the percentage of change in the dependent variable explained by independent variables is given in the table R-Square amount equals to 0.98 . 
Table 2. Detailed results from estimating the model using OLS.

\begin{tabular}{lcccc}
\hline Variable & Coefficient & Standard error & t-Statistic & Probability \\
\hline C & 10984376 & 363333.5 & 30.23222 & 0.0000 \\
LNGNP & 3.353245 & 1.188458 & 2.821509 & 0.0092 \\
LNNOE & 424.6314 & 157.0415 & 2.703943 & 0.0121 \\
LNP & 88343.53 & 15509.33 & 5.696153 & 0.0000 \\
MA(1) & 0.918518 & 0.087064 & 10.54989 & 0.0000 \\
R-squared & 0.981175 & & & \\
Adjusted R-squared & 0.978162 & & & \\
S.E. of regression & 577523.3 & & & \\
Sum squared resid & $8.34 \mathrm{E}+12$ & & & \\
Log likelihood & -437.8285 & & & \\
Durbin-Watson St. & 1.516104 & & & \\
Mean dependent V & 14806727 & & & \\
S.D. dependent var & 3908118 & & & \\
Akaike info criterion & 29.52190 & & & \\
Schwarz criterion & 29.75543 & & & \\
F-statistic & 325.7472 & & & \\
Prob(F-statistic) & 0.000000 & & & \\
Inverted MA roots & -0.92 & & & \\
\hline
\end{tabular}

Dependent variable: LNEM; Method: Least square; Date: 05.12.2011; Time: 13:27; Sample: 1980 - 2009; Included observations: 30; Convergence achieved after 13 iterations; Backchat: 1979.

\section{Conclusion}

In this study we have outlined the relationship between unemployment and impacts of non-oil exports on employment. So non-oil exports should be considered as one of the strategies to increase employment and reduce unemployment, by economic units, agents and policy makers. In this paper, the relationship between employments, non-oil exports, gross domestic product (GDP), consumer price index are reviewed. According to experimental results the logarithmic functions show a better estimate, so the logarithmic functions are used to estimate and explain the relationships between variables. Results showed that increasing non-oil exports, lead to increase in employment and reduced unemployment during the study period.

\section{ACKNOWLEDGEMENT}

Authors wish to thank Mrs A. Amininejad for her help and guidance.

\section{REFERENCES}

Abu Anvari A, Khoshkar A (2006). "Effect of Macroeconomic Factors on Income Distribution in Iran", J. Econ. Res. p.58.

Amuzegar J (2004). "Iran's Unemployment Crisis", Middle East Econ. Survey $47(41): 1-11$.
Central Bank of Iran (2011). Economic Time Series Database, Economics Statistics Department Statistics, (Accessed 12 October 2011). Available from URL: http://tsd.cbi.ir/DisplayEn/Content.aspx

Froyen RT (1998). "Macroeconomics: Theories and Policies", 6th Edition, Upper Saddle River, NJ: Prentice Hall.p45-51

Goharian MA (1995). "Management of Non-Oil Exports: Principles of Exports", Institute of Business Research, Tehran. p.368

Gourdon J, Maystre N, Melo JD (2006). "Openness, Inequality and Poverty: Endowments Matter", World Bank Policy Research Working Paper 3981.

Gujarati DN (1995). "Principles of Econometrics", 3rd ed., McGrawHill, Inc., New York pp.718-720.

Joshi RM (2005). "International Marketing", Oxford University Press, New Delhi, New York pp.405-407.

Karimi Z (2008). "Financing Job Guarantee Schemes by Oil Revenue: The Case of Iran", The Levy Economics Institute of Board College, Working Paper No:527.

Mehdi S (2011). "Effect of Foreign Trade on Economic Growth in Iran", Econ. Affairs 56(2):217-221.

Press TV (2011). "Iran Non-Oil Exports up 42,5\%", (Accessed 10 September 2011), Available from URL: http://www.edition.presstv.ir/detail/195471.html.

Sexton RL (2008). "Exploring Economics", Fourth Edition, Thomson South-Western Publication, USA. p 514-842

Shirinbakhsh SH, Khansari Z (2005). "Application of Eviews in Econometrics", Institute Econ. Affairs Tehran p.582.

Valadkhani, A. (2003). "The causes of unemployment in Iran: An empirical Investigation", Int. J. Appl Bus. Econ. Res. 1(1):21-33. 